\title{
A 5-year study of the daily food consumption of South African university students
}

\author{
BY SONIA E. WALKER \\ Department of Physiology, University of the Witwatersrand, fohannesburg
}

(Received I I November 1963-Accepted I9 August 1964)

In a preliminary report observations were made on the food consumption of a group of young South African university students comprising 136 men and 34 women (Walker, 1959). One year's class only was investigated, so variations which may have occurred from year to year could not be measured and the conclusions drawn from such a study may not have been generally applicable. Therefore, data have now been collected from five additional groups of students over the period $1959-63$, and the analysis of this material forms the basis of the study now described.

The original objects of undertaking this work were, first, to obtain information on the dietary habits of this student section of the population and, secondly, to compare the findings with those for similar groups of individuals elsewhere.

\section{EXPERIMENTAL}

Subjects. Over the period I959-63 a total of 785 individuals was investigated, comprising $6 \mathrm{I}_{5}$ male and $\mathrm{I} 70$ female physiology students, in their 2 nd year of university study. Most of them resided at home, but a small number lived in university residences, hotels, boarding houses and flats. The majority were white South Africans, but in each year there were a few African, Indian, Coloured and Chinese students, most of whom lived in university residences and had food similar to that of the white students. For this reason, no attempt was made to differentiate between the dietary habits of the white and non-white students. The ages, heights and weights of the students are shown in Table $\mathrm{I}$.

Procedure. The method of dietary survey used was similar to that previously described (Walker, 1959). Each student recorded his or her food consumption for 5 consecutive days. All students kept notebooks constantly with them during this time and recorded everything consumed in terms of wet weight when it was eaten and did not rely on memory. Each evening the total quantity of food consumed in the $24 \mathrm{~h}$ was entered on record sheets by the students and the calorie value and carbohydrate, protein and fat contents were calculated from food tables provided. These were compiled from those of Fox \& Golberg (1944) and McCance \& Widdowson (1946). At the end of the 5 days the mean daily carbohydrate, protein, fat and calorie intakes were calculated by each student. Some students had access to scales and weighed their food, but the majority had to rely on approximate estimations of the quantities eaten, using household measures. 
Table I. Ages, heights and weights of male and female South African university students studied over a 5-year period

\begin{tabular}{|c|c|c|c|c|c|c|c|c|}
\hline \multirow[b]{2}{*}{ Year } & \multirow[b]{2}{*}{ No. and sex } & \multicolumn{2}{|c|}{ Age (years) } & \multicolumn{2}{|c|}{ Height (in.) } & \multicolumn{3}{|c|}{ Weight (lb) } \\
\hline & & Range & Mean & Mean & SD & Range & Mean & SD \\
\hline 1959 & $\begin{array}{r}\text { I } 210 \\
349\end{array}$ & $\begin{array}{l}18-27 \\
17-30\end{array}$ & $\begin{array}{l}20.5 \\
19.5\end{array}$ & $\begin{array}{l}69 \cdot 6 \\
65 \cdot 5\end{array}$ & $\begin{array}{l}2 \cdot 39 \\
2 \cdot 50\end{array}$ & $\begin{array}{l}118-208 \\
104-182\end{array}$ & $\begin{array}{l}155 \cdot 8 \\
131.6\end{array}$ & $\begin{array}{l}20.7 \\
19.7\end{array}$ \\
\hline 1960 & $\begin{array}{r}108 \AA \\
36 \text { 少 }\end{array}$ & $\begin{array}{l}18-26 \\
18-21\end{array}$ & $\begin{array}{l}19.9 \\
19.2\end{array}$ & $\begin{array}{l}69 \cdot 1 \\
65 \cdot 3\end{array}$ & $\begin{array}{l}2 \cdot 7 x \\
1.97\end{array}$ & $\begin{array}{l}1 \times 4-2 \text { o7 } \\
106-I^{*} 6\end{array}$ & $\begin{array}{l}151 \cdot 9 \\
132 \cdot 6\end{array}$ & $\begin{array}{l}19.0 \\
17.6\end{array}$ \\
\hline I96r & $\begin{array}{r}1080 \\
310\end{array}$ & $\begin{array}{l}18-28 \\
18-20\end{array}$ & $\begin{array}{l}20.0 \\
19.1\end{array}$ & $\begin{array}{l}69.9 \\
64.8\end{array}$ & $\begin{array}{l}2 \cdot 29 \\
1.89\end{array}$ & $\begin{array}{l}120-210 \\
102-156\end{array}$ & $\begin{array}{l}158^{8 \cdot 8} \\
129^{\circ} 4\end{array}$ & $\begin{array}{l}17 \cdot 7 \\
14.1\end{array}$ \\
\hline 1962 & $\begin{array}{r}1310 \\
42 \stackrel{+}{\circ}\end{array}$ & $\begin{array}{l}\text { I } 7-33 \\
\text { 18-39 }\end{array}$ & $\begin{array}{l}19.9 \\
19.9\end{array}$ & $\begin{array}{l}69 \cdot 9 \\
65 \cdot 0\end{array}$ & $\begin{array}{l}2 \cdot 46 \\
2 \cdot 00\end{array}$ & $\begin{array}{r}\text { I } 2-250 \\
96-167\end{array}$ & $\begin{array}{l}156 \cdot 4 \\
128 \cdot 2\end{array}$ & $\begin{array}{l}18.6 \\
16.5\end{array}$ \\
\hline 1963 & $\begin{array}{r}146 j \\
270\end{array}$ & $\begin{array}{l}17-39 \\
18-37\end{array}$ & $\begin{array}{l}20.2 \\
19.6\end{array}$ & $\begin{array}{l}69 \cdot 8 \\
64 \cdot 3\end{array}$ & $\begin{array}{l}2 \cdot 5^{8} \\
2 \cdot 21\end{array}$ & $\begin{array}{r}I I I-2 I 5 \\
92-163\end{array}$ & $\begin{array}{l}\text { I } 57 \cdot 1 \\
127 \cdot 2\end{array}$ & $\begin{array}{l}19.7 \\
16.4\end{array}$ \\
\hline
\end{tabular}

SD, standard deviation.

Table 2. Daily food consumption of South African university students over 6 consecutive years, I958-63

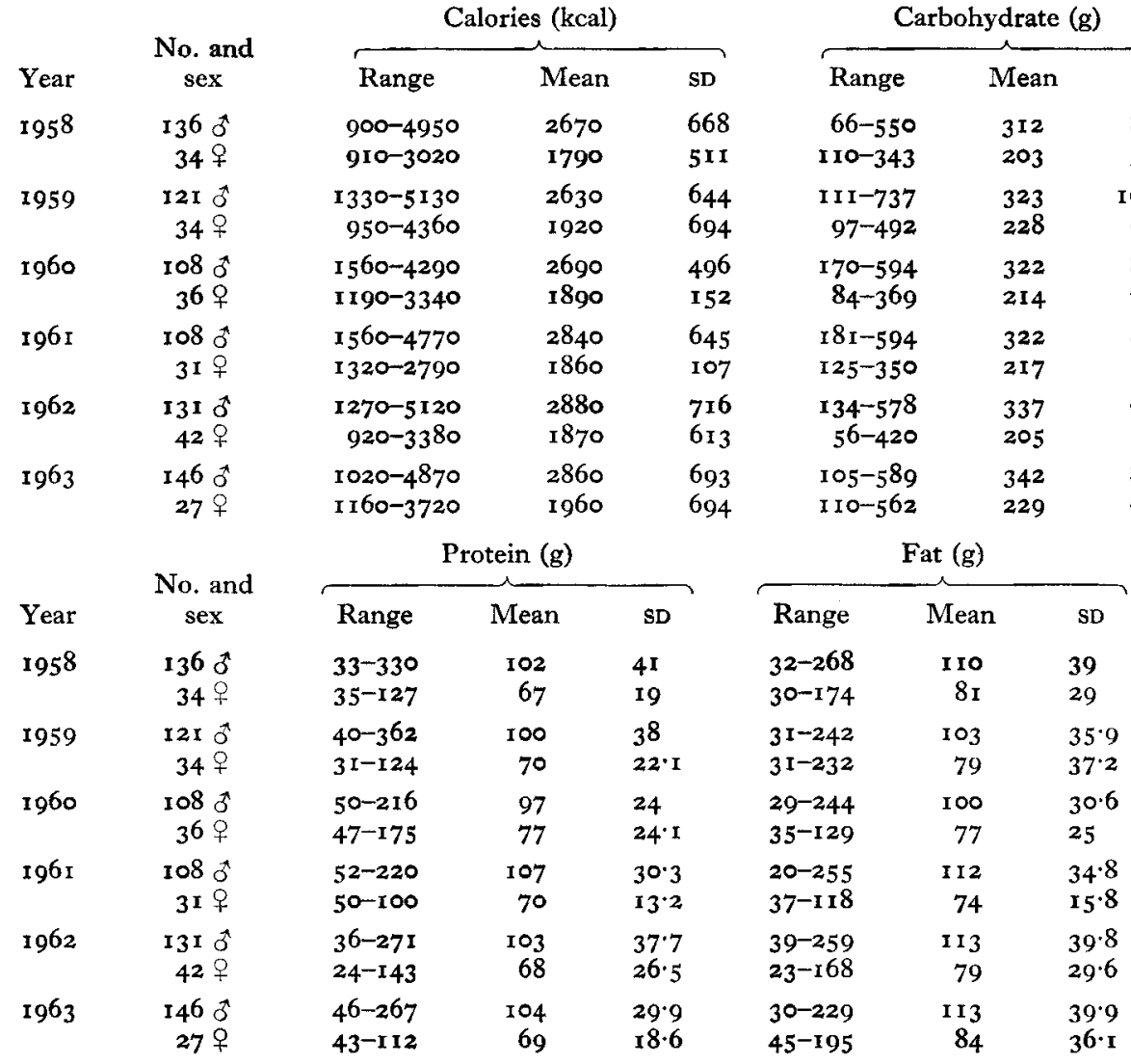

SD, standard deviation. 
Dietary records were kept from Mondays to Fridays only. Although I week is usually accepted as being the minimum time that will reflect the normal dietary pattern of an individual, in this study it was thought that any additional information gained by including weekends in the records would be nullified by inaccurate recording over Saturdays and Sundays.

All records were checked after being handed in, and students who had recorded unusually high or low consumptions of particular nutrients were questioned individually. Records obviously inaccurate were rejected.

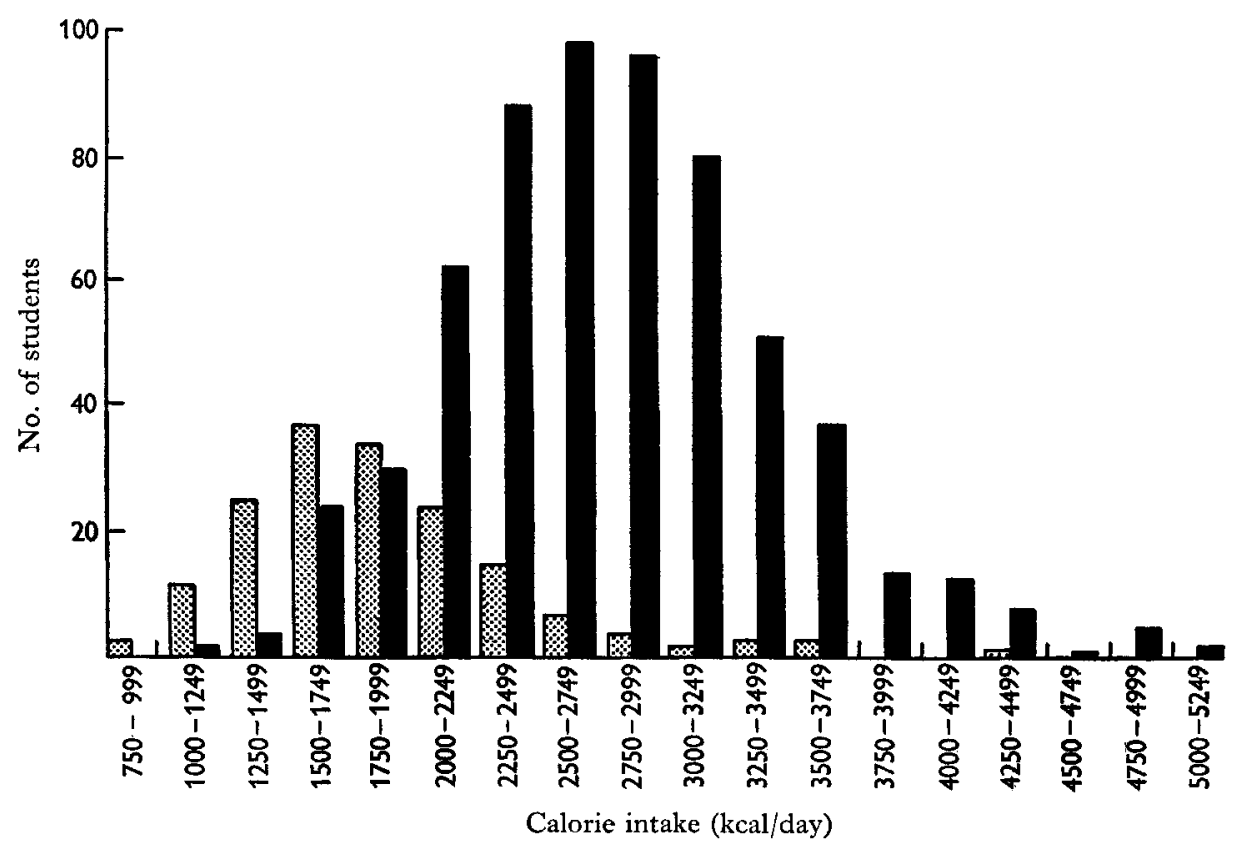

Fig. I. Frequency distribution of mean calorie intake of 6 I $_{5}$ male and 170 female students.

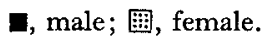

This survey was always carried out several months before the formal course in nutrition had been given. It was hoped that this timing would prevent the students from being biased by preconceived ideas of what should be eaten when they were recording their own diets.

\section{RESULTS}

Calorie intake. The mean consumption of the men was $2780 \mathrm{kcal} / \mathrm{day}$ and of the women $1900 \mathrm{kcal} /$ day. The frequency distribution of calorie intake of all the students over the 5-year period is shown in Fig. I. Of the 615 male students, $77 \cdot 2 \%$ consumed 2000-3500 kcal/day; i $1 \cdot 7 \%$ consumed $3500-4500 \mathrm{kcal} /$ day, and only $\mathrm{I} \cdot 3 \%$ consumed more than $4500 \mathrm{kcal} /$ day. A calorie intake of less than 2000 was recorded by $9.8 \%$ of the men. Of the 170 female students, $70.6 \%$ consumed $1250-2250 \mathrm{kcal} / \mathrm{day}$; for $20.6 \%$ the range was $225^{\circ}-3750 \mathrm{kcal} / \mathrm{day}$; and $8.8 \%$ consumed less than $1250 \mathrm{kcal} /$ day. 
Table 2 shows the calorie intake of the students in each consecutive year. The 1958 figures published previously (Walker, 1959) are included here for the sake of completeness. The annual variations in calorie consumption over the 6-year period were relatively small, the means for the men ranging from 2630 to $2880 \mathrm{kcal} /$ day and for the women from 1790 to $1960 \mathrm{kcal} /$ day.

No linear correlation was found between body-weight and calorie consumption in either sex in any year during the period of investigation.

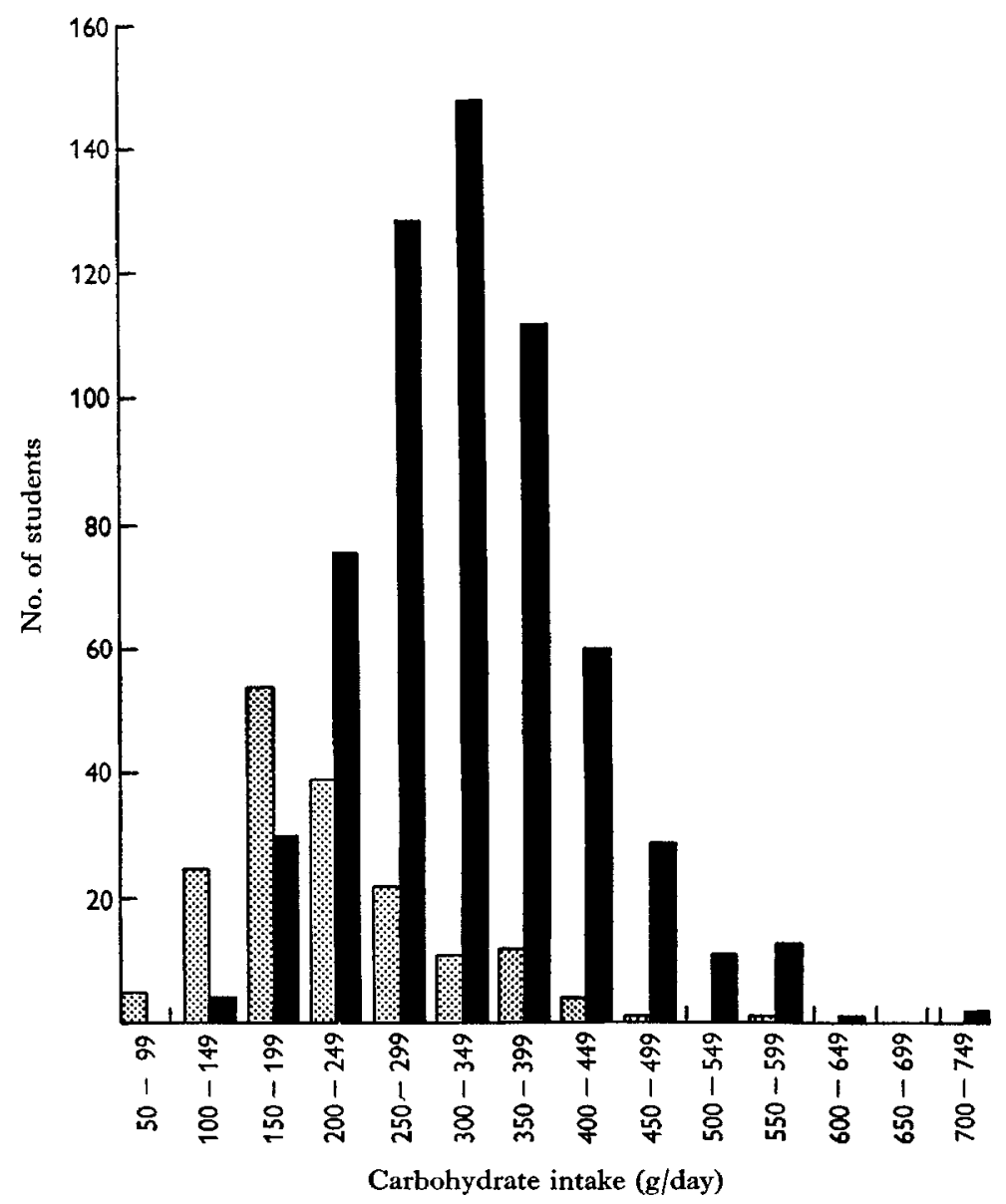

Fig. 2. Frequency distribution of mean carbohydrate intake of 6I5 male and I70 female students. $\mathbf{n}$, male; 国, female.

Carbohydrate intake. The mean carbohydrate intake of the male students was $330 \mathrm{~g} /$ day and of the female students $218 \mathrm{~g} /$ day.

Fig. 2 shows the frequency distribution of carbohydrate consumption of all students from 1959 to 1963 . From this it was found that $75.6 \%$ of the men consumed $200-$ $399 \mathrm{~g}$ carbohydrate/day; $18.4 \%$ ate from 400 to $599,0.5 \%$ from 600 to 749 and $5.5 \%$ less than $200 \mathrm{~g} /$ day. Of the women $82.4 \%$ were in the $100-299 \mathrm{~g}$ range; $14 . \mathrm{r} \%$ 
consumed $300-499 \mathrm{~g}, 0.5 \%$ ate from 550 to 599 , and $3 \%$ recorded an intake of less than $100 \mathrm{~g} /$ day.

When each year's class was examined separately (Table 2) the carbohydrate consumption showed little change from year to year, the mean intakes of the men ranging from $3 \mathrm{I} 2$ to $342 \mathrm{~g}$ and those of the women from 203 to $299 \mathrm{~g}$ carbohydrate/day.

Protein intake. The mean protein intake of the male students was $102 \mathrm{~g} /$ day, and that of the female $7 \mathrm{I} g /$ day.

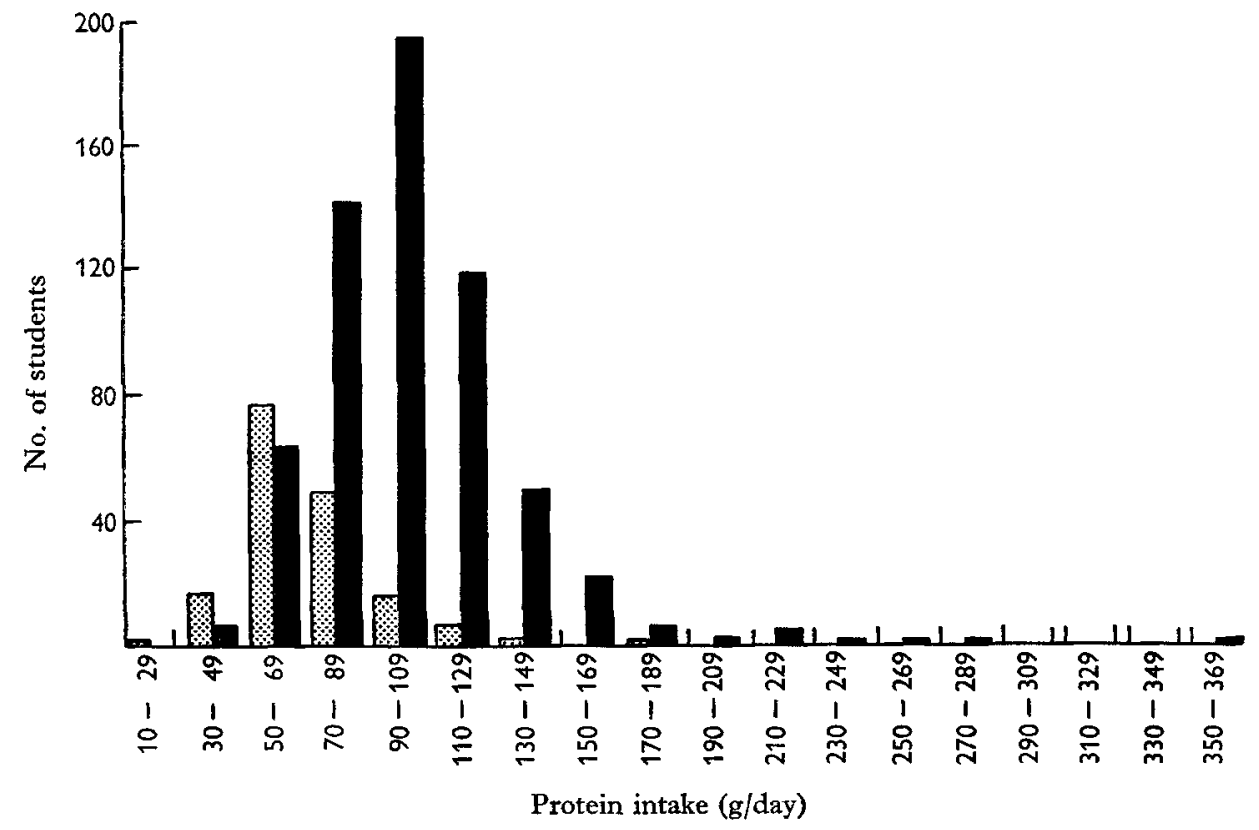

Fig. 3. Frequency distribution of mean protein intake of $61_{5}$ male and 170 female students. a, male; 国, female.

The frequency distribution of protein intake of the students (Fig. 3) showed that $74 \%$ of the men consumed $70-129 \mathrm{~g}$ protein/day; $\mathrm{r} 3.8 \%$ consumed $\mathrm{r} 30-229,0.7 \%$ from 230 to 269 and $11 \cdot 5 \%$ less than $70 \mathrm{~g} /$ day. Of the women $74 . \mathrm{I} \%$ consumed $50-89 \mathrm{~g}$ protein/day, $\mathrm{I} 5.3 \%$ ate from 90 to $\mathrm{I} 89$, and $10.6 \%$ less than $50 \mathrm{~g} /$ day.

Table 2 shows that the mean daily protein intakes of the men varied from 97 to $107 \mathrm{~g}$ over 6 years, whereas the mean daily intakes of the women for the same period ranged from 67 to $77 \mathrm{~g}$.

Fat intake. The male students consumed a mean of $108 \mathrm{~g} /$ day and the female $79 \mathrm{~g} /$ day.

Fig. 4 shows the distribution of the amounts of fat consumed. The fat intake of $76.1 \%$ of the male group was $70-149 \mathrm{~g} /$ day; $11.5 \%$ consumed $150-269 \mathrm{~g} /$ day, and $12.4 \%$ less than $50 \mathrm{~g} /$ day. Of the women, $75.2 \%$ were in the $50-\mathrm{IO} 9 \mathrm{~g}$ range; $12.4 \%$ consumed I 10-249, and $12.4 \%$ less than $50 \mathrm{~g} /$ day.

When the fat consumption in each year is considered, the mean intakes of the men ranged from 100 to $113 \mathrm{~g} /$ day, and of the women from 74 to $84 \mathrm{~g} /$ day (Table 2 ). The constancy over the 6 years was the same as for the other nutrients. 
The mean daily intakes of calories, carbohydrate, protein and fat were lower for the women than for the men. Comparison of the intakes of the 615 male and 170 female students for the 5-year period showed that the women consumed $880 \mathrm{kcal}$, I $12 \mathrm{~g}$ carbohydrate, $3 \mathrm{I} \mathrm{g}$ protein and $29 \mathrm{~g}$ fat a day less than the men. Similar differences of food intake between the two sexes occurred in each year (Table 2).

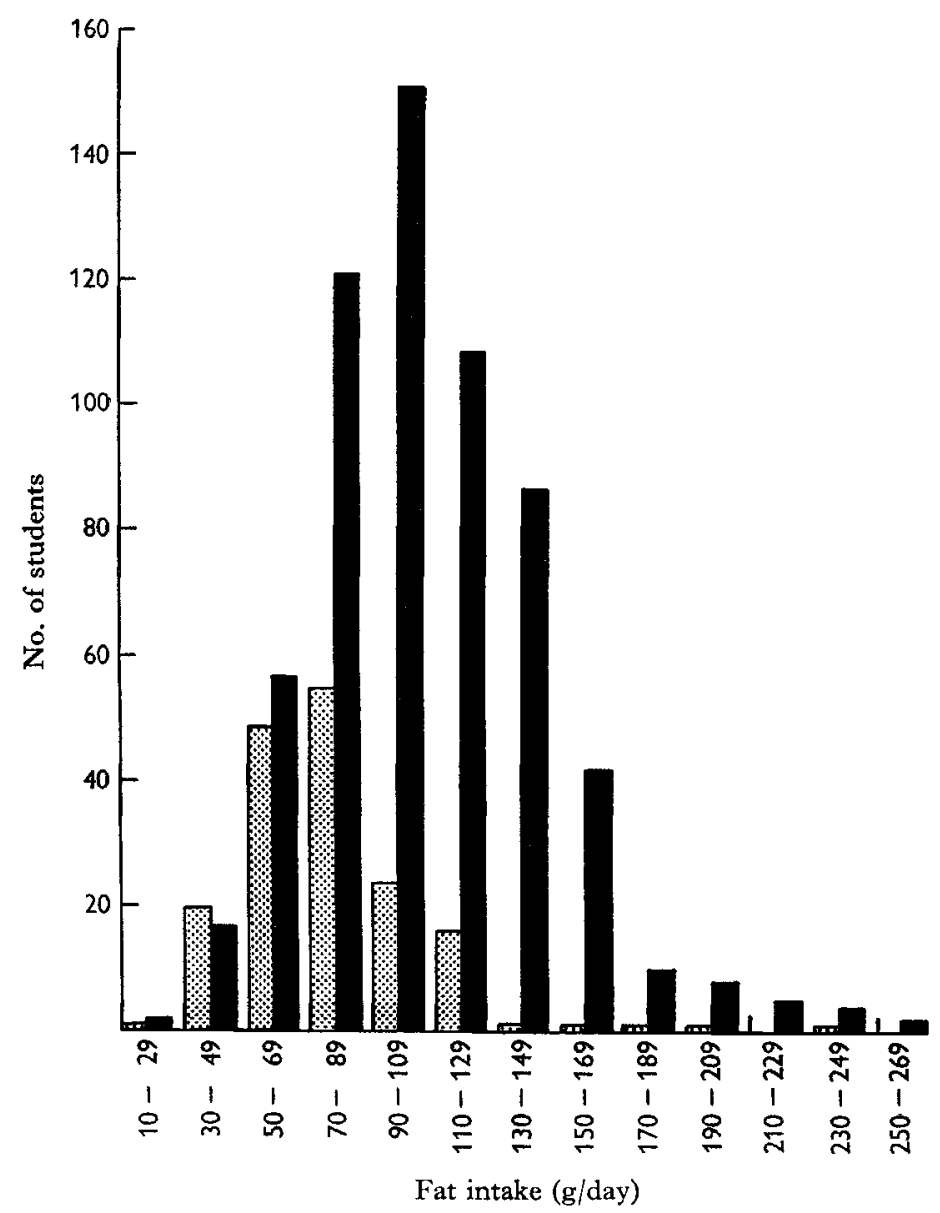

Fig. 4. Frequency distribution of mean fat intake of $6 \mathrm{r}_{5}$ male and 170 female students. D, male; 国, female.

Source of calories and 'internal balance' of diets. The percentage of calories supplied by carbohydrate, protein and fat, and the ratio of these nutrients to one another in the students' diets, were calculated from the mean daily consumption levels. The results are shown in Table 3 which also includes figures for $195^{8}$.

Over the period studied, carbohydrate provided from 44 to $49 \%$ of total calories, protein from 14 to $16 \%$ and fat from 33 to $40 \%$.

In each year the women students obtained a higher percentage of their total calories from fat than did the men. The differences were statistically significant $(P<0.02)$. There was a suggestion that the contribution of carbohydrate to total calorie intake 
was less in the women's diets than in the men's $(P<0.12)$, whereas that of protein was the same for both sexes, i.e. the differences were not significant.

The 'internal balance' of the students' diets (i.e. the ratio of carbohydrate to protein to fat) remained the same each year at $3: 1: \mathrm{I}$ by weight.

Table 3. Percentage of calories supplied from carbohydrate, protein and fat in South African university students' diets from 1958 to $1963^{*}$

\begin{tabular}{|c|c|c|c|c|}
\hline \multirow[b]{2}{*}{ Year } & \multirow[b]{2}{*}{ Sex } & \multicolumn{3}{|c|}{ Percentage calories supplied from: } \\
\hline & & Carbohydrate & Protein & Fat \\
\hline 1958 & $\begin{array}{l}0 \\
c \\
c\end{array}$ & $\begin{array}{l}47 \\
45\end{array}$ & $\begin{array}{l}\text { 15 } \\
\times 5\end{array}$ & $\begin{array}{l}37 \\
40\end{array}$ \\
\hline I959 & $\begin{array}{l}\hat{0} \\
\xi\end{array}$ & $\begin{array}{l}49 \\
48\end{array}$ & $\begin{array}{r}15 \\
\times 5\end{array}$ & $\begin{array}{l}35 \\
37\end{array}$ \\
\hline 1960 & $\begin{array}{l}\hat{O} \\
\dot{a}\end{array}$ & $\begin{array}{l}48 \\
45\end{array}$ & $\begin{array}{l}14 \\
16\end{array}$ & $\begin{array}{l}33 \\
37\end{array}$ \\
\hline I $96 \mathrm{r}$ & $\begin{array}{l}\hat{0} \\
\text { क }\end{array}$ & $\begin{array}{l}45 \\
47\end{array}$ & $\begin{array}{l}15 \\
15\end{array}$ & $\begin{array}{l}35 \\
36\end{array}$ \\
\hline 1962 & $\begin{array}{l}\hat{0} \\
\hat{q}\end{array}$ & $\begin{array}{l}47 \\
44\end{array}$ & $\begin{array}{l}14 \\
15\end{array}$ & $\begin{array}{l}35 \\
38\end{array}$ \\
\hline 1963 & $\begin{array}{l}\hat{8} \\
0 \\
0\end{array}$ & $\begin{array}{l}48 \\
47\end{array}$ & $\begin{array}{l}14 \\
14\end{array}$ & $\begin{array}{l}36 \\
39\end{array}$ \\
\hline
\end{tabular}

* The contribution of alcohol to total calorie intake has not been included.

Individual variations in calorie consumption. In each year's class there was a small number of students who were repeating their year's study and who, therefore, recorded their food consumption twice, with a year's interval between each recording. To get some idea of the variation in an individual's food consumption from one year to another, forty repeat students were selected at random - ten from each of 4 years-and the differences between their mean daily calorie intakes in 2 successive years were calculated. In twenty-one $(52.5 \%)$ of the students, the calorie intake in the 2 nd year differed from that in the Ist year by less than $10 \%$. In eleven students $(27.5 \%)$ the differences between the two calorie intakes ranged from Ir to $28 \%$ and in the remaining eight students $(20 \%)$ the differences in successive recordings were between $3 \mathrm{I}$ and $67 \%$. The increase in calorie intake from 5 -day samples in successive years was $+6 \%$ on average, which was not significantly different from zero, and the SD was $\pm 21 \%$.

\section{DISCUSSION}

It is appreciated that the method used in this survey for measuring food consumption is not ideal. In the first place, because individual supervision of such large numbers of students was not practicable, there must have been considerable variation between them in the care and accuracy with which the records were kept. Furthermore, the use of household measures to assess food quantities is unlikely to be completely accurate. Some workers have found this method to be satisfactory (Burke, 1947; Rose \& Williams, 1961), whereas others believe that it results in over- or underestimation of the amount of food consumed (Morrison, Russell \& Stevenson, 1949; 
Bransby, Daubney \& King, 1948-9; Thomson, 1958). Another difficulty is the difference in composition between the foods eaten and those listed in the tables. This applies particularly in South Africa where no adequate tables of foods grown or produced locally are available. However, as the object was to show trends in dietary habits rather than to establish absolute amounts of nutrients consumed, it is believed that valid conclusions can be drawn from this survey.

The students participating in this investigation can be classed as sedentary workers, especially for the 5-day period over which their dietary records were kept. From Monday to Friday they start the day with a lecture at $8 \mathrm{am}$ and do not finish until $5 \mathrm{pm}$ or later, which leaves little time for sport or other active pursuits for in Johannesburg, even in mid-summer, it is dark soon after $7 \mathrm{pm}$. In a metabolism study carried out on nine of these students in 1962 , it was found that $72 \%$ of their day was spent sitting in laboratories, lectures and dissecting halls and in sleeping (Wyndham, Walker \& Morrison, 1964). This figure is likely to be representative of the majority of the students as the teaching time-table remains much the same from year to year. The students' daily energy expenditures, therefore, should be very similar, once allowance has been made for the age, sex and body-weight of individual subjects. Despite this uniformity of physical activity, the mean daily calorie intakes showed considerable individual variations. In 615 male students intake varied from 1018 to $5^{126} \mathrm{kcal} /$ day and in 107 female from 916 to $43^{62} \mathrm{kcal} /$ day. Similar variations have been noted by other workers. Rose \& Williams (I96r), in a metabolic study of twelve male medical students, found that they could be divided into the small eaters, who had a mean intake of $2380 \mathrm{kcal} / \mathrm{day}$, and the large eaters, with a mean intake of $4625 \mathrm{kcal} / \mathrm{day}$. These differences in mean energy intake between the two groups could not be explained on the basis of similar differences in energy expenditure, because the mean oxygen consumptions, measured under a variety of standardized conditions, were very similar in the two groups. In food consumption studies on adults (Widdowson, 1936) and children of ages ranging from I to 18 years (Widdowson, 1947) Widdowson found the calorie intakes of different individuals to vary by $100 \%$ or more. The same author, using data on energy intake and output of mine workers, clerks and military cadets, also found no relation between the calorie intake of the subjects and their rates of energy expenditure lying and sitting (Widdowson, 1962). Harries, Hobson \& Hollingsworth (1962), from their analysis of British figures on energy intake and expenditure, concluded that ' when all known causes of variation are taken into account, large unexplained differences between individuals remain, though it would seem that these are less for expenditure than for intake'.

In the study now described, thirty-two of the forty repeat students recorded a change of calorie consumption of less than $30 \%$ in 2 successive years. This suggests that an individual's energy intake tends to be part of a fixed pattern for that person. Widdowson (1947) reported similar findings on children and concluded that 'the big eater remains the big eater' (Widdowson, 1962).

For the South African students no linear correlation was found between mean daily calorie intake and body-weight. This was true for both sexes over the 5-year period studied, and validates the same conclusion previously made for a smaller number of 
students (Walker, 1959). The same observation has been made with pregnant and nonpregnant women (Widdowson \& McCance, 1936; Thomson \& Billewicz, r96r), adult men (Widdowson, 1936) and American college women (Davis \& Scoular, 1957). Widdowson (1947) showed that in children calorie intake/kg body-weight varied almost as much as total calorie intake and Rose \& Williams (196r) found no relation between calorie intake and body-weight of their medical students. In fact, they reported that the large eaters tended to have lower body-weights than the small eaters-a mean weight of $75 \cdot 7 \mathrm{~kg}$ as against $8 \mathrm{I} \cdot 3 \mathrm{~kg}$. The calorie cost of physical activity is known to be closely correlated with body-weight (Durnin, I959; Wyndham et al. 1964). The apparent absence of correlation between calorie intake and body-weight suggests that energy expenditure is unlikely to be a major factor in the regulation of appetite and food consumption. Durnin (196I) came to this conclusion in his study of calorie balances of sixty-nine men and women of different ages and levels of calorie consumption. Only four of these subjects showed a positive correlation between dayto-day energy intake and expenditure.

A striking feature of the investigation described here is the surprising constancy from year to year in the students' dietary habits. In the period $195^{8-63}$ the male students' mean intake of calories ranged from 2630 to $288 \mathrm{o} \mathrm{kcal} /$ day, of carbohydrate from $3^{12}$ to $342 \mathrm{~g} /$ day, of protein from 97 to $107 \mathrm{~g} /$ day, and of fat from 100 to $\operatorname{II} 3 \mathrm{~g} /$ day. For the same period, the mean levels for the women were $1790-1960 \mathrm{kcal} / \mathrm{day}$, 203-229 g carbohydrate/day, 67-77 g protein/day, and $74-84 \mathrm{~g}$ fat/day. This constancy does not imply that there are no statistically significant differences in the students' food consumption from year to year, but the performance of a statistical significance test is considered irrelevant when the observed differences are judged to be insignificant from a practical point of view.

The 'internal balance' of the diets (i.e. the ratio, carbohydrate: protein : fat) showed no change over 6 years and was similar for both sexes.

The female students as a whole ate less carbohydrate, protein and fat than the male and recorded lower calorie intakes, although there was some overlap between the two sexes. This was found in each year's class. It is impossible to decide whether it represents a true physiological difference between the sexes, or whether it merely reflects greater self-discipline on the part of the women for cosmetic reasons.

It was also found in each year that the contribution of fat to the total calories was higher in the diets of the women than in those of the men. Although this difference between the sexes was small, it was statistically significant. This point has not been stressed in the literature, but figures of other workers appear to support this finding. Durnin, Blake \& Brockway (I957) found that for twelve middle-aged housewives fat contributed $40.5 \%$ of the total calories. For two groups of elderly women the contribution of fat to total calories was $42 \cdot 8 \%$ and $40.5 \%$ (Durnin, Blake, Allan, Shaw \& Blair, I96r; Durnin, Blake, Brockway \& Drury, I96r), whereas for elderly men fat supplied $38 \cdot 8-39 \cdot 2 \%$ of the daily calorie intake (Durnin, Blake, Allan, Shaw, Wilson, Blair \& Yuill, I96r). Observations on younger subjects show a similar trend. Male industrial workers derived $35 \%$ of their total calories from fat (Bransby, I954), and two groups of military cadets derived $3^{2}$ and $34 \%$ (Widdowson, Edholm $\&$ McCance, 
I954; Edholm, Fletcher, Widdowson \& McCance, 1955). For twelve young women, fat contributed $39.3 \%$ of total calories (Durnin et al. 1957) and for six women students of similar ages the percentage of calories derived from fat was found to range from 35 to $40 \%$, with a mean of $37.6 \%$ (Yudkin, 195I). These differences between the two sexes are small and may not be significant, but all the figures quoted show a general trend towards a higher proportion of fat in the women's diets.

The mean energy intake of the male South African students was $2780 \mathrm{kcal} /$ day. This value falls within the range reported for British male students, namely 2674$3040 \mathrm{kcal} /$ day (Harries et al. 1962). Mean calorie consumption levels of British women students, quoted by the same authors, range from 2035 to $2429 \mathrm{kcal} / \mathrm{day}$. The South African women consumed less, showing a mean of $1900 \mathrm{kcal} / \mathrm{day}$.

The mean protein intake of the South African men was $102 \mathrm{~g} /$ day. Male students in Britain were found to have a mean intake of 97-102 $\mathrm{g}$ (Kitchin, Passmore, Pyke \& Warnock, I949) and military cadets, of an age similar to the students, consumed a mean of $99 \mathrm{~g}$ (Edholm et al. 1955). The mean protein intake of the South African women was $7 \mathrm{I} \mathrm{g} /$ day. Yudkin ( $\mathrm{I} 95 \mathrm{I}$ ) reported a daily intake of $74^{.6} \mathrm{~g}$ protein by six women students, and Durnin et al. (1957) an intake of approximately $68 \mathrm{~g}$ protein/day by twelve young women working in department stores. Although the quantities consumed by these three groups of young women are similar, the protein of the South Africans' diet contributed $15 \%$ of their total calorie intake, whereas the protein intakes of the British women supplied $\mathrm{I}_{3} \cdot 8$ and $\mathrm{I}_{2} \cdot 3 \%$ respectively of the total calories consumed.

The consumption levels of carbohydrate and fat of the South African students appear to be similar to those found elsewhere.

\section{SUMMARY}

1. Food consumption records of 615 male and 170 female university students have been analysed for the period 1959-63. The men showed a mean daily intake of $2780 \mathrm{kcal}, 330 \mathrm{~g}$ carbohydrate, $102 \mathrm{~g}$ protein and $108 \mathrm{~g}$ fat. Corresponding figures for the women were $1900 \mathrm{kcal}, 218 \mathrm{~g}$ carbohydrate, $7 \mathrm{I} \mathrm{g}$ protein and $79 \mathrm{~g}$ fat.

2. There were considerable individual variations in mean energy intake by both sexes, the men consuming from 1020 to $5^{\mathrm{I}} 30 \mathrm{kcal} / \mathrm{day}$, and the women from 920 to $4360 \mathrm{kcal} /$ day.

3. No linear correlation between calorie intake and body-weight was found for either sex.

4. Of the forty students who recorded their diets in 2 successive years, thirty-two showed a difference in calorie intake between the two recordings of less than $30 \%$.

5. Over the period investigated only small differences in calorie, protein, carbohydrate and fat intakes were observed from year to year.

6. In each year the women students consumed less than the men, but derived a significantly higher percentage of their total calorie intake from fat than did the men. The contribution of carbohydrate to total calorie intake was lower for the women than for the men and that of protein was the same for both sexes. 
7. The ratio, carbohydrate:protein:fat in the students' diets was the same from one year to another.

8. The food consumption levels of the South African students are compared with those reported elsewhere.

The author is grateful to Professor C. H. Wyndham for his helpful criticism; to Miss J. van Veen for preparing the figures and to Mr A. Munro, Head of the Department of Statistics, Chamber of Mines Research Laboratories, for statistical analysis of the results. Acknowledgement is also made to all the students who co-operated in this survey.

\section{REFERENCES}

Bransby, E. R. (1954). Brit. F. Nutr. 8, 100.

Bransby, E. R., Daubney, C. G. \& King, J. (1948-9). Brit. F. Nutr. 2, 89.

Burke, B. S. (1947). \%. Amer. diet. Ass. 23, 104I.

Davis, A. N. \& Scoular, F. I. (1957). F. Nutr. 6r, 289.

Durnin, J. V. G. A. (1959). Brit. F. Nutr. 13, 68.

Durnin, J. V. G. A. (1961). F. Physiol. 156, 294.

Durnin, J. V. G. A., Blake, E. C., Allan, M. K., Shaw, E. J. \& Blair, S. (196I). F. Nutr. $75,73$.

Durnin, J. V. G. A., Blake, E. C., Allan, M. K., Shaw, E. J., Wilson, E. A., Blair, S. \& Yuill, S. A. (1961). Brit. F. Nutr. $15,587$.

Durnin, J. V. G. A., Blake, E. C. \& Brockway, J. M. (1957). Brit. F. Nutr. Ix, 85.

Durnin, J. V. G. A., Blake, E. C., Brockway, J. M. \& Drury, E. A. (1961). Brit. F. Nutr. 15, 499.

Edholm, O. G., Fletcher, J. G., Widdowson, E. M. \& McCance, R. A. (1955). Brit. F. Nutr. 9, 286.

Fox, F. W. \& Golberg, L. (1944). Publ. S. Afr. Inst. med. Res. 9, 123.

Harries, J. M., Hobson, E. A. \& Hollingsworth, D. F. (1962). Proc. Nutr. Soc. $21,157$.

Kitchin, A. H., Passmore, R., Pyke, M. \& Warnock, G. M. (1949). Brit. F. soc. Med. 3, 10.

McCance, R. A. \& Widdowson, E. M. (1946). Spec. Rep. Ser. med. Res. Coun., Lond., no, 235.

Morrison, S. D., Russell, F. C. \& Stevenson, J. (1949). Brit. J. Nutr. 3, v.

Rose, G. A. \& Williams, R. T. (1961). Brit. F. Nutr. 15, I.

Thomson, A. M. (1958). Brit. $\mathcal{F}$. Nutr. 12, 446.

Thomson, A. M. \& Billewicz, W. Z. (1961). Brit. F. Nutr. 15, 24 I.

Walker, S. E. (1959). S. Afr. F. med. Sci. 24, ro3.

Widdowson, E. M. (1936). F. Hyg., Camb., 36, 269.

Widdowson, E. M. (1947). Spec. Rep. Ser. med. Res. Coun., Lond., no. 257.

Widdowson, E. M. (1962). Proc. Nutr. Soc, 2I, I2I.

Widdowson, E. M. \& McCance, R. A. (1936). J. Hyg., Camb., 36, 293.

Widdowson, E. M., Edholm, O. G. \& McCance, R. A. (1954). Brit. Y. Nutr. 8, 147.

Wyndham, C. H., Walker, S. E. \& Morrison, J. F. (1964). S. Afr. J. Lab. clin. Med. ro, I.

Yudkin, J. (195I). Brit. F. Nutr. 5, 177. 